L'HOMME L'Homme

Revue française d'anthropologie

169 | 2004

Varia

\title{
Local Shamanic Knowledges
}

A Response to Guillaume Boccara

Ana Mariella Bacigalupo

\section{(2) OpenEdition \\ Journals}

Electronic version

URL: http://journals.openedition.org//homme/21628

DOI: 10.4000/lhomme.21628

ISSN: 1953-8103

Publisher

Éditions de l'EHESS

\section{Printed version}

Date of publication: 1 February 2004

Number of pages: 219-223

ISSN: 0439-4216

Electronic reference

Ana Mariella Bacigalupo, «Local Shamanic Knowledges », L'Homme [Online], 169 | 2004, Online since 01 January 2006, connection on 03 May 2019. URL : http://journals.openedition.org//homme/21628 DOI : 10.4000//homme.21628 


\title{
Local Shamanic Knowledges A Response to Guillaume Boccara
}

\author{
Ana Mariella Bacigalupo
}

HANK YOU for this opportunity to respond to historian Guillaume Boccara's review of my ethnography La Voz del Kultrun en la Modernidad: Tradicion y Cambio en la Terapeutica de Siete Machi. Boccara's lack of understanding of the anthropological literature, ethnographic methodologies and writing, and his authoritarian imposition of his own perspective cripple his ability to give a fair reading of my text. I summarize here just a selection of specific problems with Boccara's review.

I) Boccara's review contains perplexing and contradictory claims. First he states that the ethnography does not place machi (Mapuche shamans) in context of their relationships to their communities, families and patients. Then, he complains that my detailed ethnography, which is focused specifically on machi, their families, patients and communities, has a «soap opera quality» about it. By constructing machi's lives, their struggles with evil and illness, and their interactions with their families, patients and communities as «soap opera» Boccara ironically trivializes Mapuche machi as active agents in a complex constellation of relations. In doing so, he devalues the importance attending to local knowledge and meanings (Geertz 1983) and local theories on the production and reproduction of knowledge (Bourdieu 1977; Turner 1977; Merrill 1988). Moreover, his statement demonstrates his lack of familiarity with the «anthropology of the particular» (Abu-Lughod 1991) as a way of accessing local knowledge, the new narrative anthropology, dialogical anthropology (Bahktin 1981; Tedlock \& Manheim 1995), and the presence of the ethnographer in the text (Tsing 1993; Behar 1993, 1996).

2) Boccara is unable to move beyond his own interest in larger Mapuche historical processes to understand a person-centered ethnography on a specific theme. He claims that my ethnography does not focus on the historical processes that give rise to machi practice, the history of rituals, gender, the interactions of machi with political authorities or Pentecostalism. As I state clearly in the introduction, my book was never intended to serve as an encyclopedia of Mapuche machi and their rituals and history, and it was not written as a holistic, depersonalized ethnography of the sort produced in the 1950s. My purpose is to analyze the dynamic and diverse lives and practices of seven machi and their role in the processes of production and reproduction of culture. The point of the work is to challenge two stereotypes that Chilean scholars hold about 
machi : one is that machi have a homogenous culture and a unique way of practicing and two that their practices are static and unchanging and are gradually disappearing with the process of «modernization».

Those readers familiar with the literature in the field know that some of my recent work does in fact place Mapuche shamans and their rituals in the larger context of gender, history and political process. I have explored the circumstances in which women replaced men as machi, how women's knowledge of herbal remedies and traditional lore became central to machi practice, and how spiritual power is inherited through the female line (1996d). I wrote about the role gender plays in the ethnic identity, lives and ritual practices of Mapuche shamans as they interact with local and national processes (2003c). I examined the increasing feminization of spirituality and healing and the growing masculinization of political roles (2000), the new roles female machi acquired as moon priestesses (1995b, 200 Ib), the gendered symbols used by machi in healing (1998b) and Mapuche gendered rituals for cosmic order. I have also written about the struggle for machi masculinities in colonial Chile and the historical process of transformation of machi practice (2002), and about how machi gendered practices and discourses contribute to feminist debates about gendered selves and others in Third World contexts (2003b). In addition I have addressed the relationship between sorcery and sexual deviance (2003a), machi gendered negotiations with political authorities, and a transgendered machi's transgression and conformity to conflicting cultural norms. My forthcoming book Shamans of the Winter's Bark Tree: Gender, Power and Healing among the Chilean Mapuche takes up these issues in more detail.

My work also explores other aspects of Mapuche shamanism, ritual and religion. I have written about the historical and political contexts in the various manifestations of a Mapuche deity (1997), spatial organization in machi visions (1996b), diversity and consensus in machi practice (1996c), machi shamanic callings and specializations (1994a), the connection between warfare ideologies and exorcising rituals (1998a), the contested meanings of renouncing machi practice (1995a), the role machi play in the creating and complicating Mapuche identity (200la), and the relationship between Mapuche personhood and machi altered states of consciousness.

3) The first section of La Voz del Kultrun that outlines the machi powers, initiation and rituals of the seven machi is not a summary of Citarella's 1995 book as Boccara claims. My categories are taken mainly from my 1994 dissertation The Power of the Machis: The Rise of Female Shaman/healers and Priestesses in Mapuche Society. I engage with Citarella's work and that of other ethnographers as a way of comparing my findings with theirs and as a way of acknowledging their scholarship. Boccara requests that I cite a number of authors for specific non-related themes, but his references are puzzling. For example he asks me to cite Juan Carlos Gumucio and Jose Quidel on the concept of che or person, when in fact neither of these authors have written anything specific on the topic (no bibliography provided). Indeed, Boccara's critique of my work would be far more convincing if he would provide a bibliography and a clear rationale for his negative evaluation of my sources.

4) Boccara makes several claims that certain terms, rituals, practices are not used by «the Mapuche race». The concept of race is no longer used in the anthropological literature to describe people who share ethnic identity and culture. Furthermore, those familiar with the anthropological field understand that there is no single meaning for native terms. Instead, Mapuche have diverse interpretations of terms and different ways of describing and interpreting their illness and rituals. There is not one «correct way» to interpret such terms, because as is commonly assumed by contemporary anthropology, language and knowledge are dynamic, changing processes, and vary according to region, community, family, and the individual. Anthropologists such as Leila Abu-Lughod (1991) have long criticized 
homogeneous constructions of culture and there is much controversy about terminology among Mapuche themselves. For example, some Mapuche do not celebrate Wetripantu but state that they celebrate San Juan instead. Others celebrate Wetripantu and want to re-introduce this practice into Mapuche communities.

5) Boccara collapses two related but distinct concepts and imposes an outsider (etic) perspective absent among the machi I worked with. I state that the most important element in the power and prestige of a machi is the faith that the machi has in herself/himself and that others have in the machi (pp.73, 268). Boccara «corrects» my statement claiming that what I am really talking about is «symbolic power». Although faith and symbolic power (symbolic efficacy) are often related, they remain two distinct concepts. Most Mapuche use the Spanish Catholic term fé («faith») and refer to their faith in the persona of the machi as they would their faith in a particular Catholic saint, Jesus, or the Virgin Mary. Machi themselves draw on these Catholic notions of faith and sometimes self-identify with the persona of Saint Sebastian, Jesus or the Virgin Mary to «increase the faith of patients». The notion of symbolic efficacy is an anthropological concept rarely used by machi and their patients. Mapuche believe in the power (newen) inherent in nature, discourse, ritual objects and people among other things but they do not use the concept of symbol. Machi patients believe that machi ritual actions are not merely instances of symbolic efficacy but have the power to transform situations creating health out of illness, order out of disorder. The efficacy of the ritual depends on the patients' faith in ritual healing epistemologies as well as in the individual machi who may be more or less effective in ritual endeavors. A machi's ritual efficacy in a particular context will either build up or undermine the faith that led the patient to seek out this machi in the first place. Since patients talk about the ritual efficacy and personal qualities of a machi with others, a machi's ritual actions and personal charisma will - in the long run - affect her/his power and prestige.

6) Boccara argues that there is no basis for «my hypothesis» about the recent specializations of machi practice. The general statements I make in the first part of my book (pp. 29-40, 95-120) are based on my observations and conversations between 199I and 1995 with thirty-two machi from the Araucanian region who held the different specializations I outline. Moreover, these machi argue that a machi's type of calling and specialization mark their differences with other machi, that machi with the same specialization tended to cluster together in machi school of practice, while those that have different specializations often rival with each other and accuse each other of witchcraft. As I argue in my book, Catholicized moralistic machi often find themselves in conflict with those machi that practice ritual revenge; machi who inherit their spirits often conflict with those who do encounter spirits solely through perimontun («visions») and those who are initiated suddenly during natural catastrophes; machi who claim to adhere to «ancient traditional» machi practice are often critical of those who divine with tarot cards, perform love magic, or incorporate elements from Chilean popular medicine. In the second section of the book (pp. I22-268), I include the narratives of seven machi that explain how they perceive their practice in relation to those of other machi. I note that although there is some overlap between some machi specializations, each one remains a conceptual and discursive form of differentiation between machi themselves.

Machi identities and discourses are not forged primarily in the context of their communities as Boccara's claims. In fact, machi often have conflicted relationships with their communities and most of their patients come from other communities. As I demonstrate in the text, machi identities are forged mainly in the context of larger regional associations between machi from different communities who belong to the same machi school of practice and share certain specializations.

7) Boccara argues that I state that most 
machi are also sorcerers. I do not make this claim. I state instead that machi are often accused of sorcery by other Mapuche in different contexts for a variety of reasons, including their relative wealth or poverty, type of initiatory experience, particular family background, isolation from the community, relations with outsiders, challenges to traditions, and suspicions of sexually deviant behavior. Moreover, the individual machi's personality and personal conflicts influence the way they are perceived. (see pp. 203237). Thus, accusations of sorcery among machi stem from a complex set of relationships. It is a pity that the difference between accusations of sorcery, the construction of sorcerers, and the existence of sorcerers is lost to Boccara, for as I demonstrate in the book, this distinction is not lost to the Mapuche themselves.

8) Boccara claims that my book does not challenge the dichotomy of tradition and modernity. I do not propose to challenge these concepts, because machi draw upon these categories when describing themselves and their lives. In my book I explain what tradition and modernity mean to machi and how they engage with this dichotomy in creative and context-specific ways despite their hybrid healing practices. Machi often represent themselves as traditional although they incorporate many elements from Catholicism, biomedicine and mainstream pop culture in novel ways. This process has been described as the «reinvention of tradition» (Hobsbawm \& Ranger 1983). Furthermore, machi use technology, such as cars, radios, and cellular phones that the Mapuche describe as «modern» in their everyday lives. The interesting issue that currently preoccupies anthropologists (Hodgson 2002), and that I describe in the book, is why and in what

\section{BIBLIOGRAPHY}

\section{Abu-Lughod, Leila}

1991 «Writing Against Culture», in

Richard Fox, ed., Recapturing: Working in the

Present. Santa Fe, School of American

Research : 137-162.

\section{Bacigalupo, Ana Mariella}

1994a «Variación de rol de Machi en la cultura mapuche. Tipología geográfica, adaptiva e iniciática», Revista de Antropología

Universidad de Chile 12:19-43.

1994b The Power of the Machi: The Rise of Female Shaman/Healers and Priestesses in Mapuche Society. Los Angeles, University of California, Dissertation.

1995a «Renouncing Shamanistic Practice: The Conflict of Individual and Culture Experienced by a Mapuche Machi », Anthropology of Consciousness 6 (3): I - 16. 1995b «El rol sacerdotal de la Machi en los valles centrales de la Araucanía », in Modernización o sabiduría en tierra mapuche? Santiago, Chile, Ediciones San Pablo : 5।-98. 1996a «Ngünechen, el concepto de dios mapuche? » Revista de Historia (Santiago) 29: 43-68.

1996b « Identidad, espacio y dualidad en los Perimontun (visiones) de Machi mapuche», Scripta ethnologica (Buenos Aires) 18:37-63.

1996c « Imágenes de diversidad y consenso: la cosmovisión mapuche a través de trés Machi », Aisthesis (Santiago) 28: |20-|4|.

1996d «Mapuche Women's Empowerment as Shaman/Healers», Annual Review of Women in World Religions 4 : 57 129.

1997 «Las múltiples máscaras de Ngünechen : las batallas ontológicas y semánticas del Ser Supremo mapuche en Chile», Journal of Latin American Lore 20 ( I): 173-204.

1998a «The Exorcising Sounds of Warfare: Shamanic Healing and The Struggle to Remain Mapuche», Anthropology of Consciousness 9 (5): | - 16. 
1998b «Les chamanes mapuche et l'expérience religieuse masculine et féminine», Anthropologie et Sociétes 22 (2): | 23- 143. 2000 «Shamanism as Reflexive Discourse: Gender, Sexuality and Power in the Mapuche Religious Experience», in Sylvia Marcos, ed., Gender, Bodies, Religions.

Cuernavaca (Mexico), ALER Publications: 275-295.

200 la «El rol del medicinar en la recreación de la identidad mapuche: voces de resistencia, hibridez y transformación en las prácticas de Machi », Scripta ethnologica $23: 89-119$.

$200 \mathrm{lb}$ «The Rise of the Mapuche Moon Priestess in Southern Chile», Annual Review of Women in World Religions 6: 208-259.

2002 «La lucha por la masculinidad de machi : políticas coloniales de género, sexualidad y poder en el sur de chile», Revista de Historia indígena 6: 29-64.

2003a «Rethinking Identity and Feminism: Contributions of Mapuche Women and Machi From Southern Chile», Hypatia 18 (2): 32-57.

2003b «Mapuche Shamanic Bodies and the Chilean State: Polemic Gendered Representations and Indigenous Responses», in Arturo Aldama, ed., Violence and the Body: Race, Gender and the State. Indiana, Indiana University Press: 322-343.

2003c «Sorcerers as Sexual Deviants: Power and Marginality Among the Chilean Mapuche», Anthropology of Consciousness, fthcg.

fthcg Shamans of the Winter's Bark Tree: Gender, Power and Healing Among the Chilean Mapuche. Austin, University of Texas Press.

\section{Bakhtin, Mikhail}

1981 The Dialogical Imagination. Transl. by Caryl Emerson \& Michael Holquist. Austin, University of Texas Press.

\section{Behar, Ruth}

1993 Translated Woman: Crossing the Border with Esperanza's Story. Boston,

Beacon Press.

1996 The Vulnerable Observer: Anthropology

That Breaks Your Heart. Boston, Beacon

Press.

\section{Bourdieu, Pierre}

I 977 Outline of a Theory of Practice. Transl. by Richard Nice. Cambridge-London,

Cambridge University Press.

\section{Geertz, Clifford}

1983 Local Knowledge: Further Essays in Interpretive Anthropology. New York, Basic Books.

\section{Hobsbawm, Eric \& Terence Ranger}

1983 The Invention of Tradition. Cambridge, Cambridge University Press.

\section{Hodgson, Dorothy}

2002 « Introduction: Comparative Perspectives on the Indigenous Rights Movement in Africa and the Americas»,, American Anthropologist 104 (4): I 037- 1049.

\section{Merrill,William}

1988 Rarámuri Souls: Knowledge and Social Process in Northern Mexico. Washington DC, Smithsonian Institution Press.

\section{Tedlock, Dennis \& Bruce Manheim}

1995 The Dialogical Emergence of Culture. Urbana-Chicago, University of Illinois Press.

\section{Tsing, Anna Lowenhaupt}

1993 In the Realm of the Diamond Queen. Princeton, Princeton University Press.

\section{Turner,Victor}

1977 The Ritual Process: Structure and AntiStructure. Ithaca, Cornell University Press. 